\title{
Perspectives in mineral nutrition
}

\author{
By T. G. Taylor, Department of Physiology \& Biochemistry, \\ University of Southampton, Southampton $\mathrm{SO}_{9}{ }_{3} \mathrm{TU}$
}

The last symposium on poultry nutrition organized by the Nutrition Society was held in Edinburgh 13 years ago and in this paper some of the more important advances that have been made in the mineral nutrition of poultry during this period will be reviewed. This period coincides roughly with the period between the establishment by the Agricultural Research Council of the first Working Party on Nutrient Requirements of Poultry (whose report was published in 1963) and the completion of the work of its successor (Agricultural Research Council, 1975).

\section{Trace elements}

One of the most exciting developments in mineral nutrition during the past 13 years has been the extension of the list of elements known, with certainty, to be essential for poultry to include nickel, tin, vanadium, silicon and fluorine (see Schwarz (1974) for review and references).

Requirements for these newer trace elements are incredibly minute and a deficiency of most of them can only be demonstrated in animals maintained in isolators and given highly purified diets and it is not likely, therefore, that deficiencies will arise under practical conditions. It would be unwise, however, to dismiss this possibility completely. A deficiency of chromium, on the other hand, can certainly be demonstrated without the use of isolators and it may therefore turn out to be of practical significance in poultry nutrition as it is thought to be in human nutrition (Schroeder, I968).

The status of selenium has changed somewhat since $196 \mathrm{I}$; at that time a requirement for Se that could not be provided for by vitamin $\mathrm{E}$ had not been demonstrated. The identification of a Se-deficiency condition in Japanese quail and in chicks (Thompson \& Scott, 1967 ) in the presence of an abundance of vitamin $E$ established that Se was an essential trace element in its own right, and it may even prove to be the senior member of the Se-vitamin E partnership. Diplock \& Lucy (1973) have suggested that a major role of vitamin $\mathrm{E}$ may be to protect the iron-selenide active centres of certain membrane-bound proteins that play a key role in electron transport in mitochondria and possibly in the endoplasmic reticulum.

Recommended requirements for a number of the 'older' trace elements have increased in recent years. The Agricultural Rescarch Council (1963) recommended requirement for zinc for young chicks was $15 \mathrm{mg} / \mathrm{kg}$ diet, but it is now recognized 
that the true requirement is much higher than this in practical diets, but that under most husbandry conditions substantial amounts of $\mathrm{Zn}$ are derived from the environment, particularly from drinking troughs. High concentrations of calcium and phytate reduce the availability of dietary $\mathrm{Zn}$ (O'Dell, Yohe \& Savage, I964) but there are other factors, still unknown, that influence the availability of $\mathrm{Zn}$ (Turk \& Lease, 1962). The true requirement for chicks appears to be at least $40 \mathrm{mg} / \mathrm{kg}$ diet (Ziegler, Leach, Norris \& Scott, 196I) and for turkey poults $64 \mathrm{mg} / \mathrm{kg}$ (Sullivan, 196I) when soya-bean protein is used as a protein source.

The requirements of chicks for Fe appear now to be greater than the $40 \mathrm{mg} / \mathrm{kg}$ diet suggested by Hill \& Matrone (196r) and Davis, Norris \& Kratzer (1968) conclude that $75-80 \mathrm{mg} / \mathrm{kg}$ are required. As with many other nutrients, observed requirements vary somewhat according to the criteria used: with $\mathrm{Fe}$, growth, haemoglobin concentration and packed cell volume are the normal criteria employed.

\section{Calcium, phosphorus and vitamin D Metabolic studies}

Advances in knowledge concerning the metabolism of $\mathrm{Ca}$ have been truly spectacular since $196 \mathrm{r}$, beginning with the discovery of calcitonin (C'T) (Copp, Davidson \& Cheney, r 96r). Subsequent advances centred on vitamin D: on its mode of action and metabolism and on the relationships between parathyroid hormone (PTH), CT and the vitamin; much of this fundamental work was carried out in the chick.

The first indication of the mechanism of action of vitamin $\mathrm{D}$ in increasing $\mathrm{Ca}$ absorption from the gut came with the discovery that Actinomycin D, an inhibitor of protein synthesis, prevents the increase in $\mathrm{Ca}$ absorption in rachitic animals treated with vitamin $\mathrm{D}$ (Norman, 1965 ; Zull, Czarnowska-Misztal \& De Luca, r965). The following year Wasserman \& Taylor (1966) demonstrated the presence of a vitamin $\mathrm{D}$-dependent $\mathrm{Ca}$-binding protein $(\mathrm{CaBP})$ in the duodenum of normal and vitamin $D$-treated chicks and a similar protein was subsequently identified in kidney (Taylor \& Wasserman, 1967) and in the shell gland (Corradino, Wasserman, Pubols \& Chang, 1968).

During the next few years a number of biologically active metabolites of cholecalciferol were identified and we now know that the normal metabolism of cholecalciferol involves, first, hydroxylation by the liver to give 25-hydroxycholecalciferol (25-HCC) (Blunt, De Luca \& Schnoes, 1968), the main form in which vitamin $D$ is transported in the blood. Subsequently this compound is hydroxylated by the kidney to give 1,25 -dihydroxycholecalciferol ( $1,25-\mathrm{DHCC}$ ) (Lawson, Fraser, Kodicek, Morris \& Williams, I97I). This compound is the most potent derivative of vitamin $D$ known and it is now considered to be the physiologically active form of the vitamin, acting in the control of protein synthesis in target tissues at the transcription stage in a manner similar to the action of steroid hormones.

The subcellular localization of CaBP in the intestinal mucosa is still not known for certain, nor is the mechanism by which it promotes $\mathrm{Ca}$ transport understood. We 
do know, however, that in most physiological situations in the chick and in the rat there is a very close relationship between the concentration of $\mathrm{CaBP}$ in intestinal tissue and the rate of $\mathrm{Ca}$ absorption both in vivo and in vitro. Thus, for example, $\mathrm{CaBP}$ increases in response to low-Ca diets and decreases when high-Ca diets are given (Taylor \& Wasserman, 1969). It is now clear that $1,25-\mathrm{DHCC}$ is the major factor controlling $\mathrm{Ca}$ absorption by the gut of chicks (by controlling $\mathrm{CaBP}$ synthesis) and the amount of this active metabolite in the circulation is controlled in vitamin D-replete animals by changes in the activity of the $\mathrm{I}$-hydroxylase in the kidney. In normocalcaemic and hypercalcaemic states the main metabolite of $25-\mathrm{HCC}$ in the kidney is $24,25-\mathrm{DHCC}$, while in hypocalcaemic conditions 1,25 -DHCC predominates (Holick, Schnoes, De Luca, Gray, Boyle \& Suda, 1972). In the rat there would also appear to be a relationship between plasma inorganic $P$ concentration and the metabolism of $25-\mathrm{HCC}$ by the kidney: above a concentration of $2.6 \mathrm{mmol} \mathrm{P} / \mathrm{l}$, $24,25-\mathrm{DHCC}$ is the major product, while at concentrations below this $1,25-\mathrm{DHCC}$ is largely formed (Tanaka \& De Luca, 1973).

There is still some uncertainty concerning the relative importance of PTH, Ca and inorganic phosphate in controlling the activity of the kidney I-hydroxylase, but the results of in vivo experiments in the chick strongly suggest that PTH is primarily responsible for this control; a high concentration of the hormone is associated with high enzyme activity (Fraser \& Kodicek, 1973). Rasmussen, Wong, Bikle \& Goodman (1972) showed that PTH and cyclic AMP stimulated the conversion of $25-\mathrm{HCC}$ to I,25-DHCC by isolated chick kidney tubules and that CT inhibited the conversion.

\section{Practical considerations}

(a) Chicks and poults. It has been recognized for many years that minimum requirements for $\mathrm{Ca}$ and $\mathrm{P}$ vary inversely according to the amount of vitamin $\mathrm{D}$ in the diet. Thus, for example, Waldroup, Stearns, Ammerman \& Harms (1965) observed that when chicks were fed on a diet containing io $\mathrm{g} \mathrm{Ca} / \mathrm{kg}$, requirements for cholecalciferol for maximum growth and bone mineralization were no more than $5 \mu \mathrm{g} / \mathrm{kg}$, but that when the Ca concentration was reduced to $5 \mathrm{~g} / \mathrm{kg}$ diet, requirements for cholecalciferol increased to $40 \mu \mathrm{g} / \mathrm{kg}$. At this dietary concentration of cholecalciferol, growth was as good as at the higher $\mathrm{Ca}$ concentration but bone-ash percentage was greatly reduced and even at $400 \mu \mathrm{g} / \mathrm{kg}$ bone mineralization was poor. It is now possible to offer an explanation for these observations in the light of recent developments in vitamin $\mathrm{D}$ metabolism. When chicks are given a low-Ca diet the plasma $\mathrm{Ca}$ tends to fall, PTH secretion is stimulated and synthesis of $1,25-\mathrm{DHCC}$ is increased, stimulating $\mathrm{CaBP}$ synthesis in the intestinal mucosa. Provided the dietary $\mathrm{Ca}$ is only slightly reduced and the concentration of vitamin $\mathrm{D}$ in the diet is adequate, the increase in the $\mathrm{CaBP}$ in the intestines will stimulate $\mathrm{Ca}$ absorption sufficiently to allow normal growth and calcification of the skeleton. With diets seriously deficient in $\mathrm{Ca}$ this element becomes limiting for bone calcification and it may even become limiting for growth, in spite of an abundant supply of vitamin D.

Any increase in the rate of synthesis of $1,25-\mathrm{DHCC}$ (which has a very short half-life 
in the plasma) increases the dietary requirement for vitamin $\mathrm{D}$ by increasing the utilization of 25 -HCC. Vitamin D is required for growth in addition to its requirement for $\mathrm{Ca}$ absorption and for bone metabolism (striated muscle is one of the target tissues for $\mathrm{I}, 25-\mathrm{DHCC}$ ). If, therefore, supplies of vitamin $\mathrm{D}$ are not increased when the dietary $\mathrm{Ca}$ is lowered, growth will be reduced.

Turkey poults are particularly sensitive to deficiencies, relative or absolute, of $\mathrm{Ca}$ and $P$ in the diet. Neagle, Blaylock \& Goihl (1968) observed a mean live weight of $554 \mathrm{~g}$ at 4 weeks of age in poults given diets containing $8 \mathrm{~g} \mathrm{Ca}$ and $6 \mathrm{~g} \mathrm{P} / \mathrm{kg}$ and varying amounts of vitamin $\mathrm{D}$, all considered to be adequate for normal grow:th. When the dietary $\mathrm{Ca}$ was increased to $\mathrm{I} 6 \mathrm{~g} / \mathrm{kg}$ the mean weight was $484 \mathrm{~g}$ for the same concentration of $\mathrm{P}$ and the same amounts of vitamin $\mathrm{D}$. Excess $\mathrm{P}$ depressed growth in a similar manner when diets marginally deficient in $\mathrm{Ca}(6 \mathrm{~g} / \mathrm{kg})$ werc given, unless the concentration of dietary vitamin $\mathrm{D}$ was increased.

In the past we have sought to explain the inter-relationship between dietary concentrations of $\mathrm{Ca}, \mathrm{P}$ and vitamin $\mathrm{D}$ largely in terms of the availability of the minerals and the formation in the gut of insoluble complexes, especially phytates (Taylor, I 965), but it is clear that these inter-relationships must now be re-evaluated experimentally in the light of the newer knowledge of vitamin $\mathrm{D}$ metabolism. The turkey poult would seem to be an ideal subject for this re-evaluation because of its sensitivity to changes in dietary $\mathrm{Ca}$ and $\mathrm{P}$ and because of its high requirement for vitamin $\mathrm{D}$. Is growth depression on diets with high or low $\mathrm{Ca}: \mathrm{P}$ ratios associated with reduced 1,25-DHCC synthesis caused in the former instance by a depression in PTH secretion or an increased CT secretion and in the latter instance by an elevation in the plasma inorganic $\mathrm{P}$ concentration?

With the scarcity and high cost of $\mathrm{P}$ supplements it is particularly important that the fullest use should be made of the $\mathrm{P}$ in cereals and protein concentrates and that the margin of safety allowed in dietary formulations should be minimal. This emphasizes the need for the requirement for $P$ for each class of stock to be known as accurately as possible. Maximum availability of phytate $P$ is achieved when dietary $\mathrm{Ca}$ concentrations are low, so it is important that requirements for $\mathrm{Ca}$ should not be exceeded if the aim is to utilize dietary $P$ with the maximum efficiency. The Agricultural Research Council (1963) estimated requirement of $\mathrm{Ca}$ for turkey poults is $15 \mathrm{~g} / \mathrm{kg}$, but more recent reports (Nelson, Jensen \& McGinnis, 1963; Sullivan \& Kingan, 1963 ; Neagle et al. 1968) suggest that $9 \mathrm{~g} / \mathrm{kg}$ is probably adequate.

(b) Laying hens. Results of metabolic and nutritional studies with chicks and poults are consistent with the idea that the I,25-DHCC-dependent $\mathrm{CaBP}$ plays a key role in controlling $\mathrm{Ca}$ absorption by the intestines, but the situation in the laying bird is by no means so clear-cut. The two major phenomena that require to be explaincd are as follows. (1) Ca absorption increases greatly during the 10-14 d period prior to the laying of the first egg under the combined influence of oestrogen and androgen (Common, Rutledge \& Hale, 1948). (Oestrogen and androgen alone have only the smallest effect on Ca absorption.) (2) Ca absorption is about twice as great on eggforming as on non-egg-forming days (Taylor \& Kirkley, 1967).

No information has been published on the CaBP in the intestines during the 
immediate pre-laying period during which $\mathrm{Ca}$ absorption is substantially increased, but Bar \& Hurwitz (1972) observed only a slight increase in duodenal $\mathrm{CaBP}$ in pullets killed 'at the start of visible maturation' compared with birds 4 months of age killed Io d earlier. It is unlikely, however, that birds showing signs of sexual maturation had in fact reached the stage at which increased $\mathrm{Ca}$ absorption was occurring, In birds killed after laying their first egg, $\mathrm{CaBP}$ activity had increased significantly compared with immature birds and, $5^{8} \mathrm{~d}$ later, the activity was more than double that observed at the onset of reproduction. The activity declined from this time but $98 \mathrm{~d}$ after the onset of lay it was still higher than at the time of the first oviposition. Towards the end of the first laying year the $\mathrm{CaBP}$ activity had fallen to the level observed at the start of lay. Arrest of egg production by dosing birds with the drug Nicarbazin resulted in a reduction of $\mathrm{CaBP}$ to non-laying levels after $9 \mathrm{~d}$ of treatment, but on withdrawing the drug from the diet $\mathrm{CaBP}$ levels were restored within a week of resumption of production.

No increase in $\mathrm{CaBP}$ activity was observed in the duodenum of hens given a low-Ca diet for $5 \mathrm{~d}$ (Hurwitz \& Bar, 1969) but after $16 \mathrm{~d}$ on a diet containing $17 \mathrm{~g}$ $\mathrm{Ca} / \mathrm{kg}$ a slightly increased activity was observed, and after $32 \mathrm{~d}$ the increase was substantial (Bar \& Hurwitz, 1972).

No changes have been reported in $\mathrm{CaBP}$ during the egg cycle in birds laying regularly and since it is assumed that the $\mathrm{CaBP}$ synthesized in any particular mucosal cell remains for the life span of that cell (approx. $3 \mathrm{~d}$ ) it is difficult to envisage a role for $\mathrm{CaBP}$ in the short-term regulation of $\mathrm{Ca}$ absorption that occurs in relation to shell calcification. Nevertheless, differences in the activity of $25-\mathrm{HCC}$ I-hydroxylase in the kidney of Japanese quail during the egg cycle have been reported by Kenny, Lamb, David \& Losty (1974). Substantially higher activities of this enzyme were observed when shell calcification was in progress than when the shell gland was empty. It seems probable that enhanced synthesis of $1,25-\mathrm{DHCC}$ during shell formation is more likely to be related to the requirements for bone resorption than for $\mathrm{CaBP}$ synthesis by the intestines.

The available evidence suggests that there are two distinct mechanisms involved in the intestinal absorption of $\mathrm{Ca}$ in the laying hen, one $\mathrm{CaBP}$-dependent and one independent of $\mathrm{CaBP}$. It would appear that $\mathrm{CaBP}$ is largely responsible for raising the basal rate of $\mathrm{Ca}$ absorption from the non-laying to the laying rate (even on non-egg-forming days $\mathrm{Ca}$ absorption is substantially higher than in non-laying pullets or hens). Whether or not the duodenum alone is involved in this action is not known, since detailed studies of $\mathrm{CaBP}$ activities in the jejunum and ileum of laying hens do not appear to have been published. Nor is the stimulus for increasing the production of $1,25-\mathrm{DHCC}$ in laying compared with non-laying pullets known, but it may well be PTH. (It is unlikely to be oestrogens or androgens since these hormones are thought to be secreted normally in Nicarbazin-treated birds and, furthermore, Wasserman \& Taylor (1968) have demonstrated that $\mathrm{CaBP}$ is not induced by diethylstilboestrol.)

The nature of the second mechanism for $\mathrm{Ca}$ absorption, independent of $\mathrm{CaBP}$, is quite obscure, but one question that immediately arises is: 'Is it also dependent on 
vitamin D?' Hens suffering from a chronic deficiency of vitamin D can certainly absorb $\mathrm{Ca}$ : although they lay few eggs, these have normal shells, and the deficient birds often possess abnormally large amounts of medullary bone (Taylor, 1970).

In spite of the rapid advances that have been made on the basic mechanisms controlling $\mathrm{Ca}$ absorption during the last few years, there is clearly a great deal still to be learned, particularly in the laying bird. The most pressing question that needs to be answered concerns the mechanism of action of $\mathrm{CaBP}$. We also need to know what relationship, if any, exists between intestinal $\mathrm{CaBP}$ activity, shell thickness and stage of production. Which is the more important for shell thickness, $\mathrm{CaBP}$ activity or the 'second mechanism' for Ca transport? Do both mechanisms decline during the latter stages of the laying year?

Let us hope that these questions and the ones noted earlier in this paper will be answered by the time the Society next arranges a symposium on poultry nutrition in Edinburgh.

\section{REFERENCES}

Agricultural Research Council (1963). Nutrient Requirements of Farm Livestock No. I, Poultry. London: Agricultural Research Council.

Agricultural Research Council (1975). Nutrient Requirements of Farm Livestock No. 1, Poultry, 2 nd ed. London: Agricultural Research Council.

Bar, A. \& Hurwitz, S. (1972). Comp. Biochem. Physiol. 41B, 735.

Blunt, J. W., De Luca, H. F. \& Schnoes, H. K. (1968). Biochemistry, Easton 7,33 I.

Common R. H., Rutledge, N. A. \& Hale, R. W. (1948). F. agric. Sci., Camb. 38, 64 .

Copp, D. H., Davidson, A. G. F. \& Cheney, B. (196r). Proc. Can. Fedn biol. Socs $4,17$.

Corradino, R. A., Wasserman, R. H., Pubols, M. H. \& Chang, S. I. (1968). Archs Biochem. Biophys. I25. 378.

Davis, P. N., Norris, L. C. \& Kratzer, F. H. (1968). Y. Nutr. 94, 407.

Diplock, A. T. \& Lucy, J. A. (1973). FEBS Lett. 29, 205.

Fraser, D. R. \& Kodicek, E. (1973). Nature New Biol. 241, 163.

Hill, C. H. \& Matrone, G. (1961). F. Nutr. 73, 425.

Holick, M. F., Schnoes, H. K., De Luca, H. F., Gray, R. W., Boyle, I. T. \& Suda, T. (1972). Biochemistry, Easton I1, 4251.

Hurwitz' S. \& Bar, A. (1969). J. Nutr. 99, 217.

Kenny, A. D., Lamb, J., David, N. R. \& Losty, T. A. (r974). Fedn Proc. Fedn Am. Socs exp. Biol. 33, 679 Abstr.

Lawson, D. E. M., Fraser, D. R., Kodicek, E., Morris, H. R. \& Williams, D. H. (1971). Nature, Lond. 230, 228.

Neagle, L. H., Blaylock, L. G. \& Goihl, J. H. (1968). Poult. Sci. 47, 174.

Nelson, F. E., Jensen, L. S. \& McGinnis, J. (1963). Poult. Sci. 42, 579.

Norman, A. W. (1965). Science, N.Y. 149, 184.

O'Dell, B. L., Yohe, J. M. \& Savage, J. E. (r964). Poult. Sci. 43, 415.

Rasmussen, H., Wong, M., Bikle, D. \& Goodman, D. B. P. (1972). Y. clin. Invest. 51, 2502.

Schroeder, H. A. (1968). Am. F. clin. Nutr. 21, 230.

Schwarz, K. (1974). Fedn Proc. Fedn Am. Socs exp. Biol. 33, 1748.

Sullivan, T. W. (r96r). Poult. Sci. 40, 334.

Sullivan, T. W. \& Kingan, J. R. (1963). Poult. Sci. 42, 1335.

Tanaka, Y. \& De Luca, H. F. (1973). Archs Biochem. Biophys. 154, 566.

Taylor, A. N. \& Wasserman, R. H. (1967). Archs Biochem. Biophys. II9. 536.

Taylor, A. N. \& Wasserman, R. H. (1960). Fedn Proc. Fedn Am. Socs exp. Biol. 28, 1834.

Taylor, T. G. (1965). Proc. Nutr. Soc. 24, ro5.

Taylor, T. G. (1970). Annls Biol. anim. Biochim. Biophys. 10, 83.

Taylor, T. G. \& Kirkley, J. (1967). Br. Poult. Sci. 8, 289.

Thompson, J. N. \& Scott, M. L. (1967). Proc. Cornell Nutr. Conf. Feed Mfrs p. 130.

'Turk, D. E. \& Lease, J. G. (rg62). Fedn Proc. Fedn Am. Socs exp. Biol. 21, 311.

Waldroup, P. W., Stearns, J. E., Ammerman, C. B. \& Harms, R. H. (1965). Poult. Sci. $44,543$. 
Wasserman, R. H. \& Taylor, A. N. (1966). Science, N.Y. 152, 79r.

Wasserman, R. H. \& Taylor, A. N. (1968). Y. biol. Chem. 243, 3987.

Ziegler, T. R., Leach, R. M. Jr, Norris, L. C. \& Scott, M. L. (1961). Poult. Sci. $40,1584$.

Zull, J. E., Czarnowska-Misztal, E. \& De Luca, H. F. (1965). Science, N.Y. 149, 182. 